DOI: https://doi.org/10.21009/hayula.006.01.01

\title{
Living Qur'an as New Market Trends of Islamic Education in Indonesia
}

\author{
Shinta Nurani \\ IAIN Pekalongan \\ Email: shinta.nurani@iainpekalongan.ac.id \\ Luthfi Maulana \\ IAIN Pekalongan \\ Email: Luthfy.maulana@gmail.com
}

Eni Purwati

UIN Sunan Ampel Surabaya

Email: enipurwati@ uinsby.ac.id

Article Accepted: December, 14, 2021, Revised: January, 16, 2022, Approved: January 17, 2022

\begin{abstract}
Abstrak
Penelitian ini mengkaji living al-Qur'an sebagai fenomena tren dalam pembelajaran Pendidikan Islam di Indonesia. Faktor yang menyebabkannya seperti moral panic orang tua tentang kehidupan modern-kontemporer yang semakin memprihatinkan. Banyak orang tua mendorong anak-anak mereka mengamalkan al-Qur'an, dengan harapan anakanak lebih menjaga dan membentengi diri dari kehidupan bebas. Sikap moral panic para orang tua ini dimanfaatkan oleh lembaga-lembaga pendidikan Islam sebagai market untuk mendulang keuntungan kapital, seperti mendirikan rumah pendidikan berbasis pembelajaran living Qur'an. Beberapa lembaga pendidikan pun menawarkan konsep Islamic Boarding School, Rumah Tahfidz, dan berlomba-lomba mengggunakan alQur'an sebagai brand product mereka. Penelitian pustaka ini menggunakan pendekatan ilmu fenomenologi sosial dengan teori living Quran. Penelitian ini menemukan bahwa trend pendidikan living Qur'an dalam pembelajan agama Islam di lembaga-lembaga pendidikan Islam Indonesia sebagai dampak sosial dari merebaknya moral panic. Adanya moral panic pada orang tua peserta didik menjadi ladang bisnis baru para pengelola lembaga pendidikan agama Islam sehingga kajian al-Quran merupakan produk yang memiliki pangsa pasarnya tersendiri yang melahirkan fenomena living al-Quran sebagai tren metode pendidikan Islam di Indonesia.
\end{abstract}

Kata Kunci: Modernitas, Living Qur'an, Tren Market dan Pendidikan Islam.

\begin{abstract}
This research reviewed living Al-Qur'an as phenomenon and trend in learning Islamic Education in Indonesia. The causing factor is such as the moral panic of parents about modern-contemporary life. Many parents encourage their children to practice the AlQur'an, with the hope that the children will be more careful and fortify themselves from a free life. The panicked moral attitude of these parents is used by Islamic educational institutions as a market to gain capital gains, such as establishing an educational house/center based on living Qur'an learning. Several educational institutions also offer
\end{abstract}


the concept of Islamic Boarding School, Tahfidz Center, and compete to use the AlQur'an as their product brand. This literature research used a social phenomenological science approach with the living Quran theory. This research found that the trend of living Qur'an education in Islamic learning in Indonesian Islamic educational institutions was as a social impact of the spread of moral panic. The moral panic among parents of students became a new business field for managers of Islamic religious education institutions so Qur' an studies is a product that has its own market share which the phenomenon of living al-Quran was as a trend of Islamic education methods in Indonesia.

Keywords: Modernity, Living Qur'an, Market Trends and Islamic Education.

\section{Introduction}

Currently, Islamic education in Indonesia has emerged with various trends in the establishment of educational institutions with the learning model of the implementation of the Al-Qur'an as a style of Islamic education. This learning model uses a learning program by carrying out the method of memorization as well as the application of the commands and prohibitions of the Al-Qur'an in the educational element, as well as adding to the implementation of the values of the Al-Qur'an that have been taught by the Prophet as a new style for carrying out the sunnah of the Prophet Muhammad in the era of contemporary.

This model of education is considered as an answer to people's anxiety as well as supporting a religion-based character learning model as an alternative way to alleviate various problems and hope to achieve better human resources. However, without realizing it, the above programs are in line with the trend of the new method presented in Islamic education. It is the living al-Qur'an method, as a category to launch a product approach to how the Al-Quran was revealed and emerged in the midst of the life of Indonesian Muslim society.

Education with the living Al-Qur'an model appears in several places, such as the Daar al-Furqan Islamic Boarding School, Janggalan, Kudus Regency. It is one of the Islamic educational institutions that implements the practice of living the Al-Qur'an. Siti Fauzanah found in her research that the boarding school applies regulations that teach students to practice selected letters in the Al-Qur'an, such as Yasin, al-Mulk, al-Waqi'ah, Ad-Dukhan, and ar-Rahman letters. The letters are read in accordance with the agreed rules, such as after praying in congregation. This living Qur'an education program generates social awareness, in which students feel they have found the essence of themselves, life in the pesantren community, and the value of obligations that must be obeyed (Fauziah, 2014).

Muhammad Ali thought otherwise. This study of the living Qur'an is a complement to the study of the Al-Qur'an that has been more textual and theoretical. According to Ali, the 
study of the Qur'an in the West, the Middle East and in Indonesia is still dominant in discussing textuality and contextuality, but the emphasis has not been on experience and practice. Al-Quran practiced means the lived Quran, no longer thematic and methodological. Therefore, all this time, Ali said, the Qur'an is approached with the theory of pluralism and feminism. While the living Qur'an has not been applied, even though the direct practice aspect is an important matter (Ali, 2015).

However, even though this study of the living Qur'an is a paradigm shift from textbased studies to context and ultimately to practice, the research of Afriadi Putra and Muhammad Yasir sees that the study of the living Qur'an is still in the stage of finding its most mature form. Putra and Yasir traced models of the study of the Qur'an from the early hijriyah century to contemporary developments in the $21^{\text {st }}$ century. Thus, they came to the conclusion that the study of the living Qur'an is a new matter but requires maturation of the concept from all sides. (Putra \& Yasir, 2018).

Septiana Purwaningrum went further in researching how the Al-Qur'an is practiced. In her findings, Purwaningrum saw the importance of practicing the Al-Qur'an in science education in schools. The verses and narrations related to science are chosen to be used as subject matter. Therefore, the world of Islamic education such as in schools obtains a holistic understanding of the integration of Islam and Science. Students understand and carry out religious teachings that have scientific nuances, and this can be started from school education (Purwaningrum, 2015).

Based on Ade Imelda Frimayanti, living Qur'an education is not only a matter of integration with science and technology, but rather practice in the field of morals and morality. Because, the main core of Islamic religious education is value education, there are noble values and wise character. Those are moral values. Al-Qur'an becomes the basis for formulating these values, so that the daily behavior of students goes according to the values of the Al-Qur'an. In other words, the purpose of education, materials, methods, evaluation activities, as well as educators are directed to morality or character. Thus, students' daily lives can be realized and implemented. The lives of students are kept away from all negative influences caused by changing times. With Quranic morals, students can better anticipate despicable traits due to changing times (Frimayanti, 2017).

Furthermore, Living Qur'an programs in Islamic education such as Islamic boarding schools can also be translated as tahfizul Qur'an and Tahsinul Qur'an activities. As happened in the case of the Nurul Ummah Islamic Boarding School, Kotagede, Yogyakarta, 
Muhammad Shaleh Assingkiliy and R. Umi Baroroh saw that the tahfid and tahsin programs had been implemented since the education level of Madrasah Ibtidaiyah or elementary school level. (Assingkiliy \& Baroroh, 2017). In other words, the living Qur'an is open to students since elementary school education and this is proven in the case of the living Qur'an at MI Nurul Ummah.

In another research, Assingkily not only saw that the living Qur'an was worthy of being initiated from the Ibtidaiyah age and its equivalent. The Living Qur'an as in the case of MI Nurul Ummah can also be translated to explore the potential and talents of students, used as the basis for character education, especially in the context of facing global economic changes that lead to industry 4.0. Living Qur'an at MI Nurul Ummah is an al-Qur'an education that is directed to equip students with characters and talents that are suitable for economic competition in the industrial era. (Assingkiliy b, 2019).

In the hands of researchers about living Qur'an, the model of living Qur'an studies is widening, not only dwelling in the local community, but also in learning and educational materials in the classroom. Its epistemological and axiological values theoretically, but also drawns into daily cases of political, idealistic, and social movement nuances. Abdul Muiz, et al., examined the students of IAIN Kendari who often used verse 125 of Surah an-Nahl in conducting demonstrations on campus, then used their understanding of the verse as an ideological basis to criticize all campus policies. Abdul Muiz, et al., then criticized the communication behavior of students after seeing the level of understanding of the demonstrators on the verses of Al-Qur'an. For Abdul Muiz, there are some substantial things that the students do not understand about the meaning of the Koran which they use to demonstrate against campus policies. (Muiz, Danial, Gaffar, \& Syamsuddin, 2018).

The findings of Abdul Muiz, et al., are very likely to occur hypothetically. Because, as xplained by Didi Junaedi, this living Al-Qur'an approach seeks to capture the process of social interaction with the Qur'an, as IAIN Kendari students use Al-Qur'an as an ideology of resistance to their campus. The Living Qur'an in Didi Junaedi's findings at the As-Siroj alHasan Islamic Boarding School, Pabedilan, Cirebon Regency, is not limited to textual meaning. Living Qur'an places more emphasis on aspects of applying the texts of the Qur'an in everyday life, including such as students at IAIN Kendari. In fact, Didi Junaidi said that the application of the Qur'anic texts could develop further by becoming an institutionalized tradition in people's daily lives.(Junaedi, 2015). 
As the Living Qur'an can be institutionalized in people's daily lives, all lines of social life can become dimensions of the application or practice of Al-Qur'an. Research conducted by Nur Kholis, et al., showed that the living Qur'an can be applied in the form of activities to explore Al-Qur'an (tahfidz, iqra', tahsin, tarjamah, khotmil Qur'an at students' homes, Reading Al-Qur'an, competitions, sticking verses of Al-Quran in each class, and pray using Quranic verses). In addition, the living Qur'an also concerns Birrul walidain. It is praying for parents, piety, politeness. Finally, the living Qur'an can also be in the form of practicing values that make the Qur'an a guide to life, reading the Qur'an is understood as a rewarding act, making the Qur'an a source of information and knowledge for all matters of life in this world and the hereafter, and firmly believe with heart, that the Qur'an is a holy book that brings the truth (Kholis, Mufidah, \& Indriharta, 2019).

Abu Fawaz added that the living Qur'an can also occur in Health Agencies. By raising the phenomenon of the "Movement to Read the Qur'an Before Work" at the Sultan Agung Islamic Hospital, Semarang, Abu Fawas through his research concluded that the employees of the Sultan Agung Islamic Hospital Semarang interpret the movement to read the Qur'an before work both physically and mentally. Outward understanding for employees is the belief that reading the Qur'an is an obligation, need, and routine. While the inner meaning of their activities of reading the Qur'an before work is as a motivation for life, calming the heart, a means of self-introspection, and saving charity in the hereafter. (Fawaz, 2019).

Abu Fawas also stated that the living Qur'an activities in health institutions has a great influence. This influence was felt directly by the employees of RSI Sultan Agung. In their findings, employees claimeded to be encouraged to be more obedient to time discipline, establish togetherness among others, and reminded each other among employees. They were also eager to tahsin Al-Qur'an, istiqomah in reading al-Qur'an. The movement to read the Koran before work is a work program that is promoted by the directors of the Sultan Agung Islamic Hospital and is well received by its employees. (Fawaz, 2019).

This research is interesting because it sees that the research of the living Qur'an is in the vortex of educational business trends, and offers to put the Qur'an into practice as part of the marketed educational product. By making the living al-Qur'an a new theme of education, the education market is increasingly finding its interest, and of course educational institutions as producer agents are looking for consumers from the community (parents, guardians of students) to register their children in these institutions. institutions that offer living Qur'an programs. 
The hypothesis that the world of education has an' affair' with the capitalist business world is a hypothesis that has been found by many previous studies. Purwanto even mentioned that educational institutions must compete in the free market in order to offer the quality of education that best suits the needs of the market or society (Purwanto, 2015). It is not only education in general, Islamic education in particular has been trapped in the vortex of capitalism or the education business (Rosyid, 2019), but by exemplifying the pesantren education model, Miftachul Ulum still persists by defending Islamic education and making it a representation of criticism of capitalistic education. (Ulum, 2018). The pros and cons of the involvement of Islamic education in the business cycle of capitalism make research on the Living Qur'an in the area of Education more interesting, and it is expected to contribute novelty to the previous findings.

Living Qur'an is a new vocabulary derived from English. Iy literally means the living Qur'an. Literally, the living Qur'an refers to the person of the Prophet Muhammad, not to one type of study in the science of the Qur'an. The Prophet Muhammad was called the living al-Qur'an because he was Insan Kamil, a perfect human being, and haf the most sublime personality among all of God's creation. This is the reason the Holy Prophet is called the living Qur'an (Tan, 2014). Prophet Muhammad SAW taught the Qur'an, and practiced the Qur'an fully in his daily life.

Living Qur'an has developed into a new type of study name in the study of the Qur'an since it was introduced by Heddy Shri Ahimsa-Putra. He classified the meaning of the living Quran into three types: first referrs to the figure of the Prophet Muhammad based on a hadith narrated by Siti Aisyah. second refers to a social group of people whose daily lives use the Al-Qur'an as a reference book, and third refers to the meaning of the Al-Quran itself, not as a text only, but as a living text, which is lived, practiced, and manifested in daily practice (Junaedi, 2015).

From the three categories of Heddy Shri Ahimsa-Putra, we can draw an understanding of the meaning of living Qur'an education. It is the daily life of a social community based on the Qur'an, imitating the daily life of the Prophet, in the context of education. While education is also of many kinds, both from the point of view of Western intellectuals and Indonesian intellectuals. John Dewey, for example, called education as a process of forming fundamental, emotional skills, towards nature and fellow human beings. Meanwhile, Ki 
Hajar Dewantara stated that education is an effort to advance the character, mind and body of children. Thus, they can advance the perfection of life, and bring children to life in harmony with nature and society (Neolaka \& Neolaka, 2017).

Hence, the living Quran that occurs in the realm of education is an inculcation of the values and content of Al-Quran to direct humans to have fundamental, emotional skills, noble character, in harmony with society and their natural environment, all of which are based on the values of the Al-Qur'an. This is the definition used in this study. So, living Qur'an education touted as an Islamic educational activity trapped in the business vortex of the capitalists must be measured by the economic values produced.

In order to see the business and economic aspects, living Qur'an education must be equipped with the principles of what capitalist business is. Sutamat Arybowo, et al., said that business ventures that develop as a capitalist economic system always pursue profit, so that in the realm of capitalism, relationships between humans form relationships such as business.(Arybowo, Retnowati, \& Buchari, 2008). From this case, the notion of living Qur'an education in the vortex of new market trends Islamic education can be understood as education that sells the discourse of living Qur'an, yet there are aspects of capitalism.

\section{Research Method}

This research was a type of library research that deals directly with text, data, numbers, and not with direct knowledge from the field (Zed, 2008). Thus, information regarding living Qur'an education that enters the business vortex of capitalism is also taken from previously available library information. However, the text, information, and anything else that becomes the material for the analysis of this research is still about social phenomena. Text is a phenomenon beyond the consciousness of the human intellect. Ali Romdhoni considered text as a language phenomenon (Romdhoni, 2016). Furthermore, Radita Gora mentioned that text as a natural phenomenon that is still mysterious, in which the text as an object must be interpreted (Gora, 2014).

Therefore, this study used phenomenology as a research approach. Approach means the way the researcher deals with the object of research, and the approach chosen in this study was a qualitative approach because phenomenology is part of a qualitative approach (Endraswara, 2006). Education using the Living Qur'an as part of the socio-religious reality allows it to be approached with this phenomenological approach. Peter Connolly revealed that the idea of a phenomenological study of religion is an attempt to justify the study of 
religion based on its own terms rather than the point of view of theologians or social scientists (Connolly, 2002).

By trying not to get trapped up in the definitions of theologians and social scientists, such as Peter Connolly's suggestion, the author tried to first discuseds the important terms that have been formulated by social scientists, namely the living Qur'an. Furthermore, author distinguished what is meant by social scientists conceptualized by social scientists and what actually happened in social reality.

\section{Research Finding}

\section{The Definition of Living Qur'an}

Living Quran comes from two words: first isLiving that means life and Al-Qur'an as a holy book for Muslims. Living al-Qur'an can be interpreted as the Qur'an that lives in the midst of society. At first, Living al-Qur'an stems from the phenomenon of social life which always refers their actions and life orientation to Al-Qur'an. Living al-Qur'an is a daily activity practiced based on the guidance of the Qur'an(Syamsuddin (ed.), 2007).

Even if it does not refer to concrete actions, Living al-Qur'an can also be referred to ideal thoughts that support the idea of Living al-Qur'an. It is the practice Al-Qur'an in daily life. Mansyur revealed that the Living al-Qur'an is a practice as well as the meaning of the Qur'an through practical daily actions. (Mansyur \& dkk., 2007).

Thus, the Living al-Quran can be interpreted with several different meanings: first, the Al-Qur'an is the real life of the Prophet Muhammad. It is based on a verse that the character of the Prophet Muhammad is the Al-Qur'an. Siti Aisyah ra., stated that the character of the Prophet Muhammad is Al-Qur'an. From Siti Aisyah's statement, the Prophet Muhammad can also be understood as the living Quran; He is the Al-Qur'an that manifested in a human figure (Putra H. S., 2012).

Second, Living al-Qur'an can also refer to people who carry out their daily activities based on the directions in Al-Qur'an and hadith. There is not a single business in the world, including social, political, economic, cultural, artistic, and others, that is outside the guidance of the Qur'an. Such socio-religious practice can be called the Living al-Qur'an behavior. Third, the Living al-Qur'an also means that the Qur'an is a guide for the "living book," which anyone can practice in their daily lives. At this level, Al-Qur'an is the ontological basis for the Living al-Qur'an(Putra H. S., 2012). 
According to Muhammad Mansyur, living al-Qur'an is a phenomenon of Quran in Everyday Life. Emphasis on the definition of everyday life means imagining that the meaning and function of the Qur'an can be found in every line of Muslim life. Besides, from people's attitudes, living al-Qur'an is a study that looks at how the social behavior of the community in using the Qur'an as a guide for their practical life. As a paradigm, Living alQur'an sees the process of the practice of community life based on Al-Qur'an. Every decision and action are analyzed in terms of what the Qur'an teaches. Because living al-Qur'an requires all social behavior based on efforts to implement the Qur'an (Mansyur \& et all., 2007).

As quoted by Mansyur, the social response to the Qur'an can be said as the Living Qur'an, whether the Qur'an is seen by the public as a profane science or as a life guide that has sacred values. Thus, the study of the Living Qur'an does not rely on its textual existence but on social phenomena that are born and related to the presence of the Qur'an, both present in certain geographic areas and at certain times (Mansyur \& dkk., 2007).

It is possible to offer the Qur'an interpreted as an everyday practical experience, especially since humans themselves are symbolic creatures, who are accustomed to interpreting symbols such as texts into practical daily life. Humans are symbolic creatures that can create meaning for all the actions of their lives on earth (Cassirer, 1945). Offering the Living al-Qur'an as an object of study, basically, is to offer the phenomenon of human interpretation or the process of translating and interpreting the Qur'an and Hadith as a sacred text. Hence, their lives become holy, as long as they follow the direction of the Quran according to their own interpretation.

Humans as symbolic creatures carry socio-cultural phenomena to the arena of conversation about meaning. It means placing anthropological-hermeneutical, or anthropological-interpretive, assumptions and paradigms as the basis for thinking. From these foundations of thinking, humans examine and discuss the symptoms they face.

Heddy Shri Ahimsa Putra talks about one of the basic assumptions of the anthropological-interpretive paradigm. Humans are animal symbolicum. They are able to use, create, and develop symbols in order to convey messages from one individual to another. This symbol is interpreted as everything. From this meaning, long follow-up processes emerge and are very important for the nature of human life (Putra H. S., 2012).

The Living Al-Qur'an in this study does not discuss from its ontological and epistemological aspects, but from social phenomena or axiological functions of the Living 
Qur'an itself. From some of the discussions found, the Living al-Qur'an does not exist in an empty historical space, but the phenomenon of the Living al-Qur'an is preceded by a long series of complicated and complex human life, both concerning economic, political, social, cultural, and social life, religion, to art. These precedents are very broad, and this study discusses only one precedent, namely moral panic, education, capitalism ambitions, and the Living al-Qur'an as the end product of this complex journey.

\section{Living al-Qur'an and Moral Panic}

Sociologically, the increase in public interest in educational services that offer the Living Qur'an teaching method started with a moral panic. The various impacts of modernity such as colonialism, secularism, liberalism, and Westernization that led Islamist to worry about the decreasing role that Islam was playing in society and in the state (Fuad, 2019: 187). Tri Wahyuni said that the presence of religion in public schools is not a form of privatization or exclusion of certain ideologies (Wahyuni, 2019). Reading the Al-Qur'an, for example is more of a benchmark for instilling religious values in schools because people think that there is no other standard of goodness that is more applicable and in accordance with the needs of the Indonesian people besides the cultivation of the values of the Qur'an.

Tri Wahyuni in this study introduced a concept of moral panic or Moral Panic (KM). Schools, government, and community institutions have experienced a moral panic, when people no longer believe in value standards other than Al-Qur'an. As a provider of educational services, school educational institutions, according to Tri Wahyuni, practice an activity in the form of reading the Qur'an in public spaces. Some consider that the reading Al-Qur'an is an act of exclusion, namely spending on communities who are not so sure or have different views. However, Tri Wahyu denied it and put forward the opinion that it was a social phenomenon about the symptoms of moral panic (Wahyuni, 2019).

This Moral Panic is statistically reasonable. The Ministry of Youth and Sports (Kemenpora) stated that during 2008, the number of reported crimes was 346,921 incidents. From a number of reported cases, there were 197,423 men and women perpetrators. The description of criminals in 2008 was marked by concern with the increasing number of criminals who were still children and teenagers. It was revealed that in 2008 , based on the police report as a whole, the number of children and adolescents who were involved in criminal acts was 3,280 people, consisting of 2,797 men and 483 women, an increase of 4.3 percent compared to 2007 which was 3,145. person (KEMENPORA, 2009). 
The number of juvenile delinquencies that lead to criminal acts is the most appropriate reason for the moral panic of parents, school institutions, and the government. When this moral anxiety increases and school institutions become the place for juvenile delinquency, then there is no other choice but to seek Islamic education that is applicable, and immediately visible concrete evidence of its success, including the issue of Living al-Qur'an. This moral panic does not only occur in official educational institutions, but also in the midst of informal religious groups, such as certain religious social organizations. Modernity and all its derivative effects are the reason for the emergence of a moral panic that threatens their existence claiming to be the spreaders of religion (Nurani, 2019).

In other words, moral destruction or changes in adolescent behavior, especially those at the age of students, tend to be negative. It caused unrest in the hearts of all elements, parents, society, managers of formal and informal educational institutions, as well as the government. One of the causes is modernity. It is changes in the flow of information media and technology. In this kind of moral panic, Al-Qur'an-based character education becomes a basic need of society. Al-Qur'an is believed to be able to restore the morality of students (Hakim, 2014).

As chains that can't be broken from one another, modernity causes students' behavior that tends to be negative, which is then responded with moral panic by all elements of society, including education managers, government and society, then a shared belief arises that the Al-Qur'an is one the only alternative. In the end, educational institutions implement the living Quran as an answer to the needs of the community. At this point, educational institutions that offer services to the community's needs, including character building through Living al-Qur'an, will receive a positive response from the community.

\section{Living al-Qur'an: Business in Education}

Zelka Afriami and Elva Rahmah said that in modern era, it is difficult for parents to monitor children's interactions, especially when they are familiar with laptops and smartphones. In Padang city, many parents enroll their children in extracurricular activities such as tutoring and studying Islam. Many also leave their children at the Tahfidz Qur'an Center. From the many Tahfidz centers in Padang city, parents are confused about finding a place with an affordable cost. In fact, according to the findings of this research, parents sometimes regret sending their children to one of the Tahfidz Center, while elsewhere, there 
are other Tahfidz Center with better facilities and more affordable prices. (Afriami \& Rahmah, 2017).

The issue of cost is an important matter in the education of the Tahfidz Qur'an Center. Furthermore, Afriami and Rahmah said, cost is an element that people consider in choosing a Tahfidz Qur'an Center. Most people want affordable costs (Afriami \& Rahmah, 2017). Competition in providing affordable prices and quality educational services is a matter of education business competition.

In a website for providing services for memorizing $30 \mathrm{juz}$ of Al-Qur'an, it is said that the cost of a superior program that can be followed by various ages, professions and backgrounds to memorize the Qur'an with a target of 30 juz is IDR 5,000,000 (Khadimulquran, 2020). In this kind of social phenomenon, when memorizing Al-Quran, it requires operational and management costs, the question arises, how far do the education and Islamic businesses meet? Habiburrahman said that between Islam and Capitalism, there is a meeting point (Habiburrahman, 2019).

Furthermore, Habiburrahman said, humans are not only ordered to worship Allah SWT, but also commanded to pay attention to their worldly needs. They should try their best and mind to acquire wealth. The purpose of the business is to meet their daily needs. Such teachings of Al-Qur'an are in line with the principles of capitalism taught by Ayn Rand through Max Weber, which says that the spirit of capitalism is the attitude of humans in meeting their needs (Habiburrahman, 2019). This language in the findings of Islamic economics is considered a common thing, as quoted by Maulidizen, Kholid said that the spirit of capital in religion is considered a natural thing in the elements of world life which in turn is also for provision of worship in supporting the afterlife (Maulidizen, 2019).

Habiburrahman's conclusion, the spirit of the verses of Al-Qur'an teaches the spirit of capitalism is relevant to the practice of one of the educational institutions that offers teaching services for tahfidz al-Qur'an at a cost of five million rupiah. Meanwhile, on the other hand, the public's moral panic in seeing the behavior of their children who are difficult to control makes al-Qur'an education services an urgent need. Spending money for moral salvage is as important as making money for the need for moral services. This vicious circle is spinning, as the business of capitalism in general. The fact, it is currently developing in Indonesia.

Hisanori Kato explained that Islamic capitalism exists in Indonesia. According to him, in Indonesia, Islam is used to maintain the continuity of motivation and business ethics of employees in several companies. Taking the example of Ary Ginanjar Agustian's business, 
the Emotional and Spiritual Quotient (ESQ) project, Islam is used as the basis of education. One of the ESQ project collaborations was with Krakatau Steel, one of the largest companies in Indonesia. Furthermore, based on the research report, Ary Ginanjar Agustian said that Islam can't be separated from productivity and prosperity in the global economic stage (Kato, 2014).

ESQ is part of the living Qur'an project, where the Qur'an must become the spirit of global business. Krakatau Steel as a state-owned company uses the services of Ary Ginanjar Agustian to boost morale for its employees. This is proof that the living Qur'an at the corporate level is needed, as well as another form of Islamic capitalism (Kato, 2014). Islamic religious education in general, and Qur'anic education in particular are campaigned to be an alternative for moral formation and character strengthening as well as morals, collaborates with capitalism in a very subtle and slick manner.

\section{Living Qur'an as The Phenomenon of Islamic Education Trend in Indonesia}

Living Qur'an is a phenomenon of Al-Qur'an that lives in the midst of society. The phenomenon of living al-Qur'an is a phenomenon of social life oriented towards the phenomenon of the Quran in Everyday Life (Syamsuddin (ed.), 2007). The phenomenon of the living al-Quran is becoming a trend among the Muslim community, both in the social, political, economic, cultural, artistic, etc (Putra H. S., 2012). At first, the term living alQu'ran was a method used by academics in the study of al-Quran science as a new research method to see Al-Quran in the realm of practice in people's lives. This method leads to the concept that every socio-religious action of the community carried out is related to the source of Al-Qur'an, then the action is categorized as a living al-Qur'an (Mansyur \& dkk., 2007).

However, at a later stage, the living al-Qur'an does not only occur in the realm of social religion, but also becomes a trend in the world of education. The Industrial Revolution 4.0 requires people to keep abreast of developments and changing times (Untung, 2019). In the case of this demand, he basic living al-Qur'an method then becomes part of education to cope with the effect of the global era that is completely global village. Thus, the living Qur'an learning model is considered as an answer to the anxiety of parents' moral panic towards the development of the global world.

This case happened at Pesantren Daar al-Furqon Janggalan, Kudus Regency, that implemented the practice of living al-Qur'an with the teachings of reviving the practice of the letters of Yasin, al-Mulk, al-Waqi'ah, Ad-Dukhan, and ar-Dukhan. Rahman for every 
time after finishing praying in congregation. The results of this living al-Qur'an bring students to find social piety, and direct students to the nature of themselves bringing to the nuances of happiness under the values contained in the Qur'an. (Fauziah, 2014).

Besides Pesantren al-Furqon Janggalan in Kudus Regency, Pesantren Nurul Ummah Kotagede Yogyakarta also carries out tahsin and tahfidz education programs since Madrasah Ibtidaiyah, or elementary school level. According to Assingkily, this program is intended to explore the potential and talents of students in order to face global economic changes that lead to industry 4.0 (Assingkiliy \& Baroroh, 2017).

In the same case, Padang city also appeared several houses/centers of Tahfidz. According to Zelka Afriami and Elva Rahmah, entering the modern era, it is difficult for parents to supervise children's interactions, especially for those who are already familiar with smartphones. Thus, many people in the Padang send their children in extracurricular activities to study Islam, and many also entrust their children to their children at Tahfidz Qur'an Center. (Afriami \& Rahmah, 2017).

In other cases, furthermore, the living al-Qur'an is used as a guide for science education to find the integration of the Qur'an and science as a form of proof of the greatness of the Qur'an and science that can be proven through science and technology. This method conducts learning the selection of verses of Al-Qur'an and science is chosen to be used as subject matter, so that the world of Islamic education such as in schools obtains a holistic understanding of the integration of Islam and Science (Purwaningrum, 2015). The Living Qur'an related to science education is basically not just a matter of integrating Al-Qur'an with science, but rather the practice in the field of morals and morality contained in AlQur'an. Hence, students are kept away from all negative influences that arise caused by changing times(Frimayanti, 2017).

From some of the findings above, it can be concluded that the moral panic of the community has made al-Qur'an education services an urgent need. This is what makes educational institutions compete in the free market in order to offer the quality of education that best suits the needs of the market or society (Purwanto, 2015). However, the issue of moral panic is not only used by educational institutions to answer the market and public anxiety, but also some institutions are also concerned about the various negative effects of the rapidly becoming increasingly globalized modern world. It moves several institutions to hold a living Al-Qur'an program in Institutions in Health Agencies. Through the "Al-Quran 
Movement Before Work" at Sultan Agung Islamic Hospital, Semarang, employees are required to read the Qur'an as a motivation for life, peace of mind, a means of selfintrospection, and charity savings in the hereafter. This is evidenced by the great effect felt directly by the employees of RSI Sultan Agung who claim to be encouraged to be more obedient to time discipline, establish togetherness among others, and remind each other among employees.(Fawaz, 2019). In addition to RSI, the Krakatau Steel company also embeds the living al-Qur'an as a guide for Emotional and Spiritual. This is conducted to assist the morale of employees to behave as taught in Al-Qur'an (Kato, 2014).

Some of the findings above are part of the living Qur'an trend phenomenon in the world of Islamic education as an answer to the anxiety of parents towards their children, as well as becoming a variety of business market fields in the world of education. It is undeniable that all of these are part of a social phenomenon that has recently emerged in our face, because in the past, the term education based on the Qur'an was rarely encountered, but since the emergence of various parental panics, regarding the education model based on the Qur'an Religion then emerged among us as a new style of Islamic education in Indonesia. This term is in line with a trend of a new method of Islamic studies. The living al-Qur'an or Al-Quran that lives in the midst of society in this case is in world realm of Islamic Education.

\section{Conclusion}

Living al-Qur'an is part of new trend of methods in the study of Qur'anic science and interpretation that are often used in the name of various social phenomenon that originate from the spirit of the text or content of the Qur'an. However, the phenomenon of the living Qur'an is also found in the realm of Islamic education in Indonesia. The main cause is the emergence of moral panic from parents over the progress of modern times. Thus, they think about the future of their children in order not to get involved from the various negative impacts due to The progress of modern times. Educational model based on Al-Qur'an is an answer to parents' anxiety. Besides, the living al-Qur'an in education is also part of the business market in the world of education. Hence, education as an agent of capital can facilitate its market prospects by using living-based education of Al-Qur'an. Furthermore, this phenomenon became a trend in the world of education with the emergence of al-Qur'an practice education in Islamic boarding schools, awareness of al-Qur'an education from an elementary age, to the emergence of various tahfidz cities in various cities, one of which is 
in Padang. It becomes a term called the trend of living al-Qur'an in Islamic education in Indonesia.

\section{Bibliography}

Afriami, Z., \& Rahmah, E. (n.d.). Pembuatan Direktori Rumah Tahfidz Quran Se-Kota Padang. Jurnal Ilmu Informasi Perpustakaan Dan Kearsipan, 6(1), 86-94.

Ali, M. (n.d.). Kajian Naskah dan Living Quran dan Living Hadits. Journal of Quran and Hadith Studies, 4(2), 147-164.

Ali, Mukti. (2017). Mengkomunikasikan Pendidikan dan Melestarikan Kearifan Lokal Orang Bajo. Inferensi, 11(1), 187. https://doi.org/10.18326/infsl3.v11i1.187-206

Arybowo, S., Retnowati, E., \& Buchari, M. S. (n.d.). Politik Kebudayaan dan Otonomi Daerah. Lembaga Ilmu Pengetahuan Indonesia.

Assingkily, M. S. (2019). Living Qur'an as a Model of Islamic Basic Education in the Industrial Era 4.0. Al Ibtida: Jurnal Pendidikan Guru MI, 6(1), 19. https://doi.org/10.24235/al.ibtida.snj.v6i1.3876

Assingkily, M. S., \& Baroroh, R. U. (2017). Prototipe Living Qur'an Pendidikan Dasar di Madrasah Ibtidaiyah: Studi Kasus di MI Nurul Ummah Kotagede Yogyakarta. JOIES: Journal of Islamic Education Studies, 2(1), 136-162.

Bahjatulloh, Q. M. (2016). Pengembangan Pemberdayaan Ekonomi Masyarakat Melalui Kegiatan Filantropi (Studi Kasus Lembaga Tazakka DIII Perbankan Syariah IAIN Salatiga). Inferensi, 10(2), 473. https://doi.org/10.18326/infs13.v10i2.473-494

Danandjaja, J. (2014). Metode Penelitian Kepustakaan. In Antropologi Indonesia (Vol. 0, Issue 52). Yayasan Obor Indonesia. https://doi.org/10.7454/ai.v0i52.3318

Fauziah, S. (2014). Pembacaan Al-Qur'an Surat-Surat Pilihan Di Pondok Pesantren Putri Daar Al-Furqon Janggalan Kudus (Studi Living Qur'an). Jurnal Studi Ilmu-Ilmu AlQur'an Dan Hadis, 15(1), 159. https://doi.org/10.14421/qh.2014.15108

Fawaz, A. (n.d.). Living Qur'an Di Instansi Kesehatan: Fenomena "Gerakan Membaca AlQuran Sebelum Bekerja" Di Rumah Sakit Islam Sultan Agung Semarang. HERMENEUTIK, 13(1), 117-130.

Fuad, A. F. N. (2018). The Islamists' Responses to Modernity and Their Notion of Active Da'wa. Jurnal Afkaruna, 15(2), 187-202.

Gora, R. (2014). Hermeneutika Komunikasi. In Deepublish. Deepublish. https://books.google.co.id/books?hl=id\&lr=\&id=y7eUDwAAQBAJ\&oi=fnd\&pg=PP $1 \& \mathrm{dq}=$ hermeneutika\&ots=ZXByTYfKa\&sig=sdjpU04FiRCHQlp0BTIAmcLxJw\&re dir_esc $=\mathrm{y} \# \mathrm{v}=$ onepage $\& \mathrm{q}=$ hermeneutika $\& \mathrm{f}=$ false 
Habiburrahman, H. (2019). Islam dan Kapitalisme; Titik Temu dan Kritik Dalam Al-Qur'an. Indonesian Journal of Religion and Society, 1(1), 38-50. https://doi.org/10.36256/ijrs.v1i1.23

Hakim, R. (2014). Pembentukan Karakter Peserta Didik Melalui Pendidikan Berbasis AlQuran. Jurnal Pendidikan Karakter, O(2), 123-135. https://doi.org/10.21831/jpk.v0i2.2788

Imelda, A. (2018). Implementasi Pendidikan Nilai Dalam Pendidikan Agama Islam. AlTadzkiyyah: Jurnal Pendidikan Islam, 8(2), 227. https://doi.org/10.24042/atjpi.v8i2.2128

Junaedi, D. (2015). Living Qur'an: Sebuah Pendekatan Baru dalam Kajian AlQur'an (Studi Kasus di Pondok Pesantren AsSiroj AlHasan Desa Kalimukti Kec. Pabedilan Kab. Cirebon). Journal of Qur'an and Hadith Studies, 4(2), 169190.

Kato, H. (2014). Islamic Capitalism: The Muslim Approach to Economic Activities in Indonesia. Comparative Civilizations Review, 71(71), 90-106.

Kemenpora. (2008). Penyajian Data Informasi Kementerian Negara Pemuda dan Olahraga Tahun 2008. Biro Perencanaan Sekretariat Kementerian Pemuda dan Olahraga.

Khadimulquran. (n.d.). Biaya Pendidikan Dauroh Al-Quran. https://www.khadimulquran.id/biaya/

Kholis, N., Mufidah, N., \& Indriharta, L. (2019). Implimentasi Budaya Living Quran Di Sekolah. EDUKASI: Jurnal Penelitian Pendidikan Agama Dan Keagamaan, 17(2), 125-134.

Mahfudin, R., Wajdi, F., \& Ismail, Y. (2017). Konsep pendidikan Islam KH Abdullah bin Nuh dan Relevansinya Dengan Pendidikan Islam Modern. Jurnal Studi AlQur'An, 13(2), 143-157.

Maulidizen, A. (2019). Business Ethics: Analysis of al-Ghazali's Economic Thought With Sufism Approach. Religia, 22, 160. https://doi.org/10.28918/religia.v22i2.2067

Muiz, A., Danial, Gaffar, A., \& Syamsuddin. (2018). Study Living Qur'an: The Analysis of Understanding Surah al-Nahl (125) against Demonstration-Based Communication Behavior. IOP Conference Series: Earth and Environmental Science, 175(1), 12180. https://doi.org/10.1088/1755-1315/175/1/012180

Mustakim, Abdul. (2007). Metode Penelitian Living Qur'an (S. Syamsuddin (ed.)). Teras.

Naloka, A., \& Amalia, G. (2017). Landasan Pendidikan Dasar Pengenalan Diri Sendiri Menuju Perubahan Hidup Edisi. In Cet. 1 (Issue Landasan Pendidikan.). Kencana.

Nurani, S. (2019). Salafi, Media Baru dan Moral Panic; Studi Atas Majlis Al-Khidhir. Jurnal Aqlam Journal Of Islamic and Plurality, 4(1), 134-149. http://journal.iainmanado.ac.id/index.php/AJIP/article/view/913 
Pendidikan, M. R.-A. J. M., \& 2019, undefined. (n.d.). Kapitalisme Pendidikan Islam. Ejournal.Iaiskjmalang.Ac.Id,1(2),162-175.

http://ejournal.iaiskjmalang.ac.id/index.php/akad/article/view/66

Peter Connoly (Ed.). (2002). Aneka Pendekatan Studi Agama (terj). Yogyakarta.

Pollock, R. (1946). An Essay on Man. In Thought (Vol. 21, Issue 2). Yale University Press. https://doi.org/10.5840/thought194621288

Purwaningrum, S. (n.d.). Elaborasi Ayat-Ayat Sains dalam Al-Quran: Langkah Menuju Integrasi Agama dan Sains dalam Pendidikan. Inovatif, 1(1), 124-141.

Purwanto, N. (2015). Strategi Bersaing Dalam Bisnis Pendidikan. Jurnal Manajemen Pendidikan, 7(1), 9-16.

Putra, A. (2019). Kajian Al-Qur'an Di Indonesia (Dari Studi Teks Ke Living Qur'an). TAJDID: Jurnal Ilmu Keislaman Dan Ushuluddin, 21(2), 28-36. https://doi.org/10.15548/tajdid.v21i2.221

Putra, H. S. (n.d.). The living Al-Quran: Beberapa Perspektif Antropologi. Jurnal Walisongo, 20(1), 236.

Romdhoni, A. (2019). Semiotik Metodologi Penelitian. Literatur Nusantara.

Swardi Endrawangsa. (2006). Metode, Teori, Teknik Penelitian Kebudayaan. Pustaka Widyatama.

Syamsudin, S. (2007). Metodologi Penelitian Living Qur'an dan Hadis. In TH-Press. TH. Press.

Tan, C. (2014). Reforms in Islamic Education. In Reforms in Islamic Education. Bloomsbury. https://doi.org/10.5040/9781472593252

Ulum, M. (2018). Eksistensi Pendidikan Pesantren: Kritik Terhadap Kapitalisasi Pendidikan. Tarlim : Jurnal Pendidikan Agama Islam, 1 No.2 Jul(2), 20-37.

Untung, S. (2019). Masjid Dan Aktivitas Dakwah Di Era Revolusi Industri 4.0. Religia, 22(2). https://doi.org/10.28918/religia.v22i2.2069

Wahyuni, T. (2019). Pembacaan Al-Qur'an Di Ruang Publik: Refleksi Pembentukan Karakter Religius Siswa Ditengah Kepanikanmoral. Jurnal Kajian Kritis Pendidikan Islam Dan Manajemen Pendidikan Dasar, 2(1), 80-98.

Wajdi, F., \& Aulia, R. N. (2019). Ma 'had'Aly and the Challenge of Modernizing Islamic Education in Indonesia. Hayula: Indonesian Journal of Multidisciplinary Islamic Studies, 3(2), 173-190.

Zed, M. (2008). Metode Penelitian Kepustakaan. Jakarta: Yayasan Obor Indonesia. 